\title{
MODEL PENGEMBANGAN \\ PENDIDIKAN AGAMA ISLAM DI SEKOLAH \\ Badrus Saleh
}

\begin{abstract}
Learning of Islamic Education (PAI), as a lesson containing of Islamic teachings and foundations of Islamic life, needs to be pursued through developing models for its teaching that can affect the choices, decisions, and development of the learner's life. Developing PAI model includes: a) dichotomous model; causing dualism in the education system, namely non-religious and religious education. b) mechanism model; viewing life consists of various aspects, and education is seen as an investment and development of a set of values of life, each moves and runs according to its function. c) organism model; viewing the educational activityies as a system consisting of live together and work together in an integrated manner towards a specific goal for establishment of a religious life or inspired life by religious values.
\end{abstract}

Kata kunci: PAI, sekolah, dikotomis, mekanisme, organisme 


\section{Pendahuluan}

Pendidikan Agama Islam (PAI) yang selama ini berlangsung agaknya terasa kurang terkait atau kurang concern terhadap persoalan bagaimana mengubah pengetahuan agama yang bersifat kognitif menjadi makna dan nilai yang perlu diinternasionalisasikan dalam diri peserta didik untuk bergerak, berbuat dan berperilaku secara kongkret-agamis dalam kehidupan praksis sehari-hari. ${ }^{1}$

Pelaksanaan pendidikan agama yang berlangsung di sekolah bisa dikatakan masih mengalami banyak kelemahan, bahkan bisa dikata-kan masih gagal. Kegagalan ini disebabkan karena praktik pendi-dikannya hanya memerhatikan aspek kognitif semata dari pertumbuhan kesadaran nilai-nilai (agama), dan mengabaikan pembinaan aspek afektif dan konatif-volitif, yakni kemauan dan tekad mengamal-kan nilai-nilai ajaran agama. Akibatnya terjadi kesenjangan antara pengetahuan dan pengalaman, antara gnosis dan praxis dalam kehi-dupan nilai agama. Atau dalam praktik pendidikan agama berubah menjadi pengajaran agama, sehingga tidak mampu membentuk priba-di-pribadi bermoral, padahal intisari dari pendidikan agama adalah pendidikan moral. ${ }^{2}$

Bila kita mengamati fenomena empirik yang ada di hadapan dan sekeliling kita maka tampaklah bahwa saat ini terdapat banyak kasus kenakalan pelajar. Isu perkelahian pelajar, tindak kekerasan, prema-nisme, white collar crime (kejahatan kerah putih), konsumsi minuman keras, etika berlalu lintas, perubahan pola konsumsi makanan, krimi-nalitas yang semakin hari semakin menjadi-jadi dan sebagainya, telah mewarnai halaman surat kabar dan media massa lainnya. Timbulnya kasus-kasus tersebut memang tidak semata-mata karena kegagalan PAI di sekolah yang lebih menekankan aspek kognitif, tetapi bagai-mana semuanya itu dapat mendorong serta menggerakkan guru PAI untuk mencermati kembali dan mencari solusi lewat pengembangan pembelajaran PAI yang berorientasi pada pendidikan nilai (afektif). ${ }^{3}$

\footnotetext{
1 Muhaimin, Paradigma Pendidikan Islam,Upaya Mengefektifkan Pendidikan Agama Islam di Sekolah (Bandung: Remaja Rosdakarya, 2004), hlm. 168.

${ }^{2}$ Muhaimin, Pengembangan Kurikulum Pendidikan Agama Islam di Sekolah, Madrasah, dan Perguruan Tinggi (Jakarta: RajaGrafindo Persada, 2009), hlm. 23

${ }^{3}$ Aspek afektif menyangkut kemampuan anak didik untuk menerima, berpartisipasi, menilai, mengorganisasi, serta membentuk pola hidup. Selanjutnya, aspek psikomo-torik menyangkut kemampuan anak didik untuk melakukan persepsi, melakukan gerakan terbimbing, melakukan gerakan yang terbiasa, melakukan gerakan yang kompleks, melakukan penyesuaian pola gerakan dan mengembangkan kreativitas. W.S. Winkel, Psikologi Pengajaran (Jakarta: Grasindo, 1996), hlm. 245
} 
PAI sebagai salah satu mata pelajaran yang mengandung muatan ajaran-ajaran Islam dan tatanan nilai hidup dan kehidupan Islami, perlu diupayakan melalui model pengembangan pendidikan agama yang baik agar dapat memengaruhi pilihan, putusan, dan pengem-bangan kehidupan peserta didik. Karena itu, proses pendidikan yang dilakukan pendidik diarahkan untuk membekali anak didik dengan pengetahuan, pemahaman, penghayatan pengamalan ajaran Islam. Dalam hal ini pembelajaran PAI harus menempatkan ajaran Islam sebagai suatu objek kajian yang melihat Islam sebagai sebuah sistem nilai dan sistem moral yang tidak hanya diketahui dan dipahami, tapi juga dirasakan serta dijadikan sebuah aksi dalam kehidupan anak didik. ${ }^{4}$

Tulisan ini--dengan segala keterbasannya--berikhtiar untuk meng-ungkap model pengembangan pendidikan agama Islam yang berbeda-beda yang diawali oleh adanya perbedaan pandangan dari para pemikir dan pengembang pendidikan mengenai posisi agama dalam kehidupan, apakah agama merupakan bagian dari aspek kehidupan, atau sebagai sumber nilai-nilai dan opersional kehidupan, sehingga agama akan mewarnai segala aspek kehidupan?.

\section{Memahami Pendidikan Agama Islam}

Banyak orang merancukan pengertian istilah "pendidikan agama islam" dan "pendidikan Islam". Kedua istilah ini dianggap sama se-hingga ketika seseorang berbicara tentang pendidikan Islam ternyata isinya terbatas pada pendidikan agama Islam, atau sebaliknya ketika seseorang berbicara pendidikan agama Islam justru yang dibahas di dalamnya adalah tentang pendidikan Islam. Padahal kedua istilah itu memiliki substansi yang berbeda. $^{5}$

PAI dibakukan sebagai nama kegiatan mendidikkan agama Islam. PAI sebagai mata pelajaran seharusnya dinamakan "Agama Islam", karena yang diajarkan adalah agama Islam. Nama kegiatannya atau usaha-usaha dalam mendidikkan agama Islam disebut sebagai pendidikan agama Islam. ${ }^{6}$ Sedangkan pendidikan Islam adalah nama sistem, yaitu sistem pendidikan yang islami, yang memiliki komponen-kom-ponen yang secara keseluruhan

\footnotetext{
${ }^{4}$ Akmal Mundiri, 'KOMITMEN ORGANISASIONAL SUMBER DAYA MANUSIA DALAM MENINGKATKAN MUTU PENDIDIKAN PESANTREN', Pedagogik, 3.1 (2015), 88-105.

${ }^{5}$ Muhaimin, Nuansa Baru Pendidikan Islam, Mengurai Benang Kusut Dunia Pendidikan (Jakarta: RajaGrafindo Persada, 2006), hlm.3-4

${ }^{6}$ Mundiri.
} 
mendukung terwujudnya sosok mus-lim yang diidealkan. Pendidikan Islam ialah pendidikan yang teori-teorinya disusun berdasarkan al-Qur'an dan Hadits. ${ }^{7}$

Pemahaman tentang PAI di sekolah dapat dilihat dari dua sudut pandang, yaitu PAI sebagai aktivitas dan PAI sebagai fenomena. PAI sebagai aktivitas berarti upaya yang secara sadar dirancang untuk membantu seseorang atau sekelompok orang dalam mengembangkan pandangan hidup (bagaimana orang akan menjalani dan memanfaat-kan hidup dan kehidupannya), sikap hidup, dan keterampilan hidup-- baik yang bersifat manual (petunjuk praktis) maupun mental--dan sikap sosial yang bernapaskan atau dijiwai oleh ajaran serta nilai-nilai Islam. Sedangkan sebagai fenomena adalah peristiwa perjumpaan antara dua orang atau lebih dan/atau penciptaan suasana yang dampaknya ialah berkembangnya suatu pandangan hidup yang ber-nafaskan atau dijiwai oleh ajaran dan nilai-nilai Islam, yang diwujudkan dalam sikap hidup serta keterampilan hidup pada salah satu atau beberapa pihak. ${ }^{8}$

Di dalam GBPP PAI (1999) di sekolah umum, dijelaskan bahwa PAI adalah usaha sadar untuk menyiapkan siswa dalam meyakini, mema-hami, menghayati, dan mengamalkan agama Islam melalui kegiatan

bimbingan, pengajaran, dan/atau latihan dengan memerhatikan tun-tutan untuk menghormati agama lain dalam hubungan kerukunan antar umat beragama dalam masyarakat untuk mewujudkan persa-tuan nasional. ${ }^{9}$

Ruang lingkup materi dari kurikulum pendidikan agama Islam untuk pencapaian tujuan tersebut meliputi al-Qur'an, keimanan (akidah), akhlak, fiqh, dan bimbingan ibadah, serta tarikh Islam. ${ }^{10}$

\footnotetext{
${ }^{7}$ Ibid, hlm.4. Dalam perspektif ini, PAI merupakan bagian dari pendidikan Islam. Secara lebih luas, Ahmadi mendefinisikan Pendidikan Islam sebagai "usaha yang lebih khusus ditekankan untuk mengembangkan fitrah keberagamaan (religiousity), subyek didik agar lebih mampu memahami, menghayati dan mengamalkan ajaranajaran Islam". Ahmadi menekankan kepada proses pengembangan potensi fitrah manusia untuk selalu melaksanakan ajaran-ajaran Islam, yang diawali dengan pemberian pengetahuan, pengertian dan pemahaman terhadap ajaran-ajaran Islam. Lihat Ahmadi, Ideologi Pendidikan Islam (Yogyakarta: Pustaka Pelajar, 2005), hlm. 29

${ }^{8}$ Muhaimin, Rekonstruksi Pendidikan Islam, dari Paradigma Pengembangan, Manajemen Kelembagaan, Kurikulum hingga Strategi Pembelajaran (Jakarta: Rajawali Press, 2009), hlm. 51

${ }^{9}$ Muhaimin, Paradigma Pendidikan Islam, hlm. 75-76

$10{ }^{8}$ Nurhayati Djamas, Dinamika Pendidikan Islam di Indonesia Pascakemerdekaan (Jakarta: Rajawali Press, 2009), hlm.139
} 
Dalam kebijakan kurikulum berbasis kompetensi untuk pendidikan agama Islam, selain mencantumkan ruang lingkup mata pelajaran yang sama dengan ruang lingkup GBPP di atas, ditetapkan pula standar kompetensi, yaitu kemampuan dasar yang harus dimiliki para siswa sebagai hasil dari proses pembelajaran yang meliputi:

a. Beriman kepada Allah SWT dan lima rukun iman yang lain dengan mengetahui fungsi dan hikmahnya serta terefleksi dalam sikap, perilaku, dan akhlak peserta didik dalam dimensi vertikal maupun horizontal.

b. Dapat membaca, menulis, dan memahami ayat-ayat al-Qur'an serta mengetahui hukum bacaannya dan mampu mengimplementa-sikannya ke dalam kehidupan sehari-hari.

c. Mampu beribadah dengan baik sesuai tuntunan syari'at Islam, baik ibadah wajib maupun ibadah sunnah.

d. Dapat meneladani sifat, sikap dan kepribadian Rasulullah, para sahabat, tabi'in, serta mengambil hikmah dan sejarah perkembang-an Islam untuk kepentingan hidup sehari-hari masa kini dan masa depan.

e. Mampu mengamalkan sistem muamalah Islam dalam tata kehidupan bermasyarakat, berbangsa dan bernegara. ${ }^{11}$

Dalam Peraturan Menteri Pendidikan Nasional Nomor 23 Tahun 2006 dijabarkan tentang standar kompetensi lulusan untuk satuan pendidikan dasar dan menengah dalam kelompok mata pelajaran agama dan akhlak mulia sebagai berikut :

1. Agama.Mengamalkan ajaran agama yang dianut sesuai dengan tahap perkembangan remaja. ${ }^{12}$

2. Menerapkan nilai-nilai kejujuran dan keadilan.

3. Memahami keberagaman agama, budaya, suku, ras, dan golongan sosial ekonomi.

4. Berkomunikasi dan berinteraksi secara efektif dan santun yang mencerminkan harkat dan martabatnya sebagai makhluk Tuhan.

5. Menerapkan hidup bersih, sehat, bugar, aman, dan memanfaatkan waktu luang sesuai dengan tuntunan agama.

11 Kurikulum Berbasis Kompetensi, Standar Kompetensi Mata Pelajaran Pendidikan Agama Islam, (Departemen Pendidikan Nasional, 2003).

12 Standar Kompetensi Lulusan Kelompok Mata Pelajaran Agama dan Akhlak Mulia untuk sa-tuan pendidikan dasar dan menengah sesuai dengan Peraturan Menteri Pendidikan Nasio-nal Nomor 23 Tahun 2006 
6. Memanfaatkan lingkungan sebagai makhluk ciptaan Tuhan secara bertanggung jawab.

7. Menghargai perbedaan pendapat dalam menjalankan ajaran Demikian pula standar kompetensi lulusan untuk satuan pendidikan SMA/MA dinyatakan sebagai berikut:

a. Berperilaku sesuai dengan ajaran agama yang dianut sesuai dengan perkembangan remaja

b. Menghargai keberagaman agama, bangsa, suku, ras, golongan sosial, ekonomu dan budaya dalam tatanan global.

c. Berpartisipasi dalam penegakan aturan-aturan sosial

d. Memahami hak dan kewajiban diri dan orang lain dalam pergaulan di masyarakat.

e. Menghargai adanya perbedaan pendapat dan berempati terhadap orang lain.

f. Berkomunikasi dan berinteraksi secara efektif dan santun melalui berbagai cara termasuk pemanfaatan teknologi informasi yang mencerminkan harkat dan martabatnya sebagai makhluk Tuhan.

g. Menjaga kebersihan, kesehatan, ketahanan dan kebugaran jasmani dalam kehidupan sosial sesuai dengan tuuntunan agama.

h. Memanfaatkan lingkungan sebagai makhluk ciptaan Tuhan secara bertanggung jawab. ${ }^{13}$

Dengan demikian, PAI merupakan proses penyelenggaraan pendi-dikan agama yang dimaksudkan untuk mengejawantahkan ajaran dan Pendidikan Nasio-nal Nomor 23 Tahun 2006

nilai-nilai Islam dalam kegiatan pendidikannya. Sehingga melalui proses ini akan terjadi transmisi nilai-nilai, kebiasaan-kebiasaan dan bentuk-bentuk ideal kehidupan mereka sesuai dengan ajaran-ajaran Islam. ${ }^{14}$

\footnotetext{
${ }^{13}$ Standar Kompetensi Lulusan Kelompok Mata Pelajaran Agama dan Akhlak Mulia untuk SMA/MA sesuai dengan Peraturan Menteri Pendidikan Nasional Nomor 23 Tahun 2006

${ }^{14}$ Akmal Mundiri and Irma Zahra, 'IMPLEMENTASI METODE STIFIn DALAM MENINGKATKAN KEMAMPUAN MENGHAFAL AL-QUR'AN DI RUMAH QUR'AN STIFIn PAITON PROBOLINGGO', Journal of Islamic Education Studies), 5.2 (2017), 201-23 <https://doi.org/10.15642/jpai.2017.5.2.201-223>.
} 


\section{Model Pengembangan Pendidikan Agama Islam}

Dalam realitas kehidupan sehari-hari sering timbul pertanyaan: apa saja aspek-aspek kehidupan itu? Apakah agama merupakan bagian dari aspek kehidupan, sehingga hidup beragama berarti menjalankan salah satu aspek dari berbagai aspek kehidupan, ataukah agama merupakan sumber nilai-nilai dan operasional kehidupan, sehingga agama akan mewarnai segala aspek kehidupan itu sendiri?. Dalam konteks inilah para pemikir dan pengembang pendidikan pada umumnya mempunyai pandangan yang berbeda-beda. Perbedaan ter-sebut pada gilirannya melahirkan beberapa model dalam pengem-bangan PAI sebagaimana uraian berikut:

a. Model Dikotomis

Pada model ini, aspek kehidupan dipandangan sangat seder-hana, dan kata kuncinya adalah dikotomi atau diskrit. Segala sesuatu hanya dilihat dari dua sisi yang berlawanan. Pandangan dikotomis tersebut pada gilirannya dikembangkan dalam memandang aspek kehidupan dunia dan akhirat, kehidupan jasmani dan rohani, se-hingga pendidikan agama Islam hanya diletakkan pada aspek kehidupan akhirat saja atau kehidupan rohani saja. Dengan demiki-an, pendidikan agama dihadapkan dengan pendidikan non agama, pendidikan keislaman dengan nonkeislaman, demikian seterus-nya. ${ }^{15}$

Pandangan semacam itu akan berimplikasi pada pengembangan pendidikan agama Islam yang hanya berkisar pada aspek kehidup-an ukhrowi yang terpisah dengan kehidupan duniawi, atau aspek kehidupan rohani yang terpisah dari kehidupan jasmani. Pendi-dikan (agama) Islam hanya mengurusi persoalan ritual dan spiritual, sementara kehidupan ekonomi, politik, seni-budaya, ilmu pengetahuan dan teknologi, seni dan sebagainya dianggap sebagai urusan duniawi yang menjadi garapan bidang pendidikan non-agama. Pandangan dikotomis inilah yang menimbulkan dualisme dalam sistem pendidikan, yaitu istilah pendidikan agama dan non-agama. Sikap dikotomi (dualisme) ini terkait erat dengan world view umat Islam dalam memandang dan menempatkan dua sisi ilmu, yaitu 'ilm al-dînîyah dan 'ilm ghair aldînı̂yah. ${ }^{16}$

\footnotetext{
${ }^{15}$ Muhaimin, Rekonstruksi Pendidikan Islam, hlm. 60

${ }^{16}$ Agama mengasumsikan atau melihat suatu persoalan dari segi normatif, sedangkan sains meneropongnya dari segi obyektifnya. Agama melihat problematika dan solusinya melalui petunjuk Tuhan, sedangkan sains melalui eksperimen dan rasio manusia. Karena agama diyakini sebagai petunjuk Tuhan, kebenaran dinilai mutlak,
} 
Demikian pula pendekatan yang dipergunakan lebih bersifat ke-agamaan yang normatif, doktriner dan absolutis. Peserta didik diarahkan untuk menjadi pelaku (actor) yang loyal, memiliki sikap commitment (keberpihakan), dan dedikasi (pengabdian) yang tinggi terhadap agama yang dipelajari. Sementara itu, kajian-kajian ke-ilmuan yang bersifat empiris, rasional, analitis-kritis, dianggap da-pat menggoyahkan iman, sehingga perlu ditindih oleh pendekatan yang normatif dan doktriner tersebut. ${ }^{17}$

Pola dikotomi yang demikian, telah menimbulkan sejumlah efek negatif. Abdurrahman Mas'ud dalam salah satu penelitiannya-- sebagaimana dikutip Ma'arif-menunjukkan bahwa cara pandang yang dikotomik tersebut akhirnya telah membawa kemunduran dalam dunia pendidikan Islam. Di antaranya adalah menurunnya tradisi belajar yang benar di kalangan muslim, layunya intelek-tualisme Islam, melanggengkan supremasi ilmu-ilmu agama yang berjalan secara monotomik, kemiskinan penelitian empiris serta menjauhkan disiplin filsafat dari pendidikan Islam. ${ }^{18}$

\section{b. Model Mekanisme}

Model mekanisme memandang kehidupan terdiri atas berbagai aspek, dan pendidikan dipandang sebagai penanaman dan pe-ngembangan seperangkat nilai kehidupan, ${ }^{19}$ yang masing-masing bergerak dan berjalan menurut fungsinya, bagaikan sebuah mesin yang terdiri atas beberapa komponen atau elemen-elemen, yang masing-masing menjalankan fungsinya sendiri-sendiri, dan antara satu dengan lainnya bisa berkonsultasi atau tidak.

Aspek-aspek atau nilai-nilai kehidupan itu sendiri terdiri atas nilai agama, nilai individu, nilai sosial, nilai politik, nilai ekonomi, nilai rasional, nilai estetik, nilai biofisik, dan lain-lain. Demikian juga dalam proses pendidikan dibutuhkan sistem nilai agar dalam

sedangkan kebenaran sains relatif. Agama banyak berbicara yang ghaib sedangkan sains hanya berbicara mengenai hal yang empiris. Lihat I.R. Poedjawajatna, Tahu dan Pengetahuan: Pengantar ke Ilmu dan Filsafat Ilmu (Jakarta: Bina Aksara, 1983), hlm. 62-73. Lihat juga Bustanuddin Agus, Pengembangan Ilmu-ilmu Sosial Studi Banding antara Pandangan Ilmiah dan Ajaran Islam (Jakarta: Gema Insani, 1999), hlm. 12; Muhammad Hatta, Pengantar ke Jalan Ilmu dan Pengetahuan (Jakarta: Mutiara, 1979), hlm. 40-41.

${ }^{17}$ Hasan Baharun and Akmal Mundiri, Metodologi Studi Islam: Percikan Pemikiran Tokoh Dalam Membumikan Agama, Ar-Ruzz Media, 1st edn (Yogyakarta: Ar-Ruzz Media, 2011).

${ }^{18}$ Syamsul Maarif, Revitalisasi Pendidikan Islam (Yogyakarta: Graha Ilmu, 2007), hlm.15

${ }^{19}$ Nilai adalah konsepsi abstrak di dalam diri manusia atau masyarakat mengenai hal-hal yang dianggap baik dan benar dan hal-hal yang dianggap buruk dan salah. Di samping itu, ada kecenderungan alami di dalam diri manusia ke arah kebenaran dan wujud suci tertentu, yang juga bisa berkembang lebih jauh. Lihat Murtadha Mutahhari, Perspektif al-Qur'an tentang Manusia dan Agama (Bandung: Mizan, 1984), hlm. 82-93 
pelaksanaannya berjalan dengan arah yang pasti, karena berpe-doman pada garis kebijaksanaan yang ditimbulkan oleh nilai-nilai fundamental, misalnya nilai agama, ${ }^{20}$ ilmiah, sosial, ${ }^{21}$ ekonomi, ${ }^{22}$

kualitas kecerdasan dan sebagainya. ${ }^{23}$

Oleh karena itu, jika kita membahas nilai-nilai pendidikan, akan jelas melalui rumusan dan uraian tentang tujuan pendidikan, sebab di dalam rumusan tujuan pendidikan itu tersimpul dari semua nilai pendidikan yang hendak diwujudkan di dalam pribadi peserta $\operatorname{didik}^{24}$

Demikian pula, jika berbicara tentang tujuan pendidikan Islam, berarti berbicara nilainilai ideal yang bercorak Islami. Hal ini mengandung makna bahwa tujuan pendidikan Islam adalah tujuan yang merealisasi idealitas Islami. Sedang idealitas Islami itu sendiri pada hakikatnya adalah mengandung nilai perilaku manusia yang didasari atau dijiwai oleh iman dan taqwa kepada Allah sebagai sumber kekuasaan mutlak yang harus ditaati. ${ }^{25}$

Dengan demikian, aspek atau nilai agama merupakan salah satu aspek atau nilai kehidupan dari aspek-aspek kehidupan lainnya. Hubungan antara nilai agama dengan nilainilai lainnya kadang-kadang bersifat horizontal-lateral (independent) atau bersifat lateralsekuensial, tetapi tidak sampai pada vertikal linier. ${ }^{26}$

\footnotetext{
${ }^{20}$ Dalam agama terkandung nilai-nilai yang menentukan bukan saja terhadap cara berfikir, akan tetapi juga terhadap pandangan hidup, sikap hidup dan perilaku hidup. Lihat Soekarno dan Ahmad Supardi, Sejarah dan Filsafat Pendidikan Islam (Bandung: Angkasa, 1983), hlm.19

${ }^{21}$ Dalam nilai sosial, masyarakat tradisional mengutamakan kehidupan kolektif atau kekerabatan. Dapat dikatakan, masyarakat tradisional lebih berorientasi pada kohesivitas kehidupan. Sesuai dengan kerangka nilai semacam itu, pola hubungan sosial di antara mereka diartikulasikan dalam bentuknya yang komunal dan personal. Lihat Tobroni dan Syamsul Arifin, Islam Pluralisme Budaya dan Politik, Refleksi Teologi untuk Aksi dalam Keberagamaan dan Pendidikan (Yogyakarta: SI Press, 1994), hlm.116

${ }^{22}$ Dalam nilai ekonomi, masyarakat tradisional lebih berorientasi pada pemenuhan kebutuhan dasar (basic need) dengan insentif yang bersifat moral dan sosial. Kecende-rungan ini bisa saja terjadi karena tingkat persaingan masyarakat dalam bidang sosial-ekonomi tidak begitu ketat, dan yang terpenting, ukuran kehidupan masyarakat belum ditentukan dengan tingkat pemilikan benda-benda ekonomi. Lihat Ibid
}

\footnotetext{
Pengantar Pedagogik (Dasar-dasar Ilmu Mendidik) (Jakarta: Rineka Cipta, 1997), hlm.10 Pendidikan (Jakarta: Gaya Media Pratama, 2002),hlm.115

${ }^{25}$ M. Arifin, Filsafat Pendidikan Islam (Jakarta: Bumi Aksara, 1994), hlm. 119

${ }^{26}$ Muhaimin, Pengembangan Kurikulum Pendidikan, hlm.36
}

${ }^{23}$ Muhaimin dan Abdul Mujib, Pemikiran Pendidikan Islam, Kajian Filosofis dan Kerangka Dasar Operasionalisasinya (Bandung: Trigenda Karya, 1993), hlm.124. Bandingkan dengan Burhanuddin Salam,

${ }^{24}$ Mohammad Noor Syam, Filsafat Pendidikan dan Dasar Filsafat Pendidikan Pancasila (Surabaya: Usaha Nasional, 1986), hlm.140. Lihat juga Jalaluddin dan Abdullah Idi,Filsafat Pendidikan, Manusia, Filfasat dan 
Relasi yang bersifat horizontal-lateral (independent), mengandung arti bahwa beberapa mata pelajaran yang ada dan pendidikan agama mempunyai hubungan sederajat yang independen, dan ti-dak saling berkonsultasi. Relasi yang bersifat lateral-sekuensial, berarti di antara masing-masing mata pelajaran tersebut mempunyai relasi sederajat yang bisa saling berkonsultasi. Sedangkan relasi vertikal linier berarti mendudukkan pendidikan agama sebagai sum-ber nilai atau sumber konsultasi, sementara seperangkat mata pela-jaran yang lain termasuk pengembangan nilai insani yang mem-punyai relasi vertikal linier dengan agama.

Dalam konteks tersebut, selama ini di sekolah-sekolah masih ada proses sekularisasi ilmu, yakni pemisahan antara ilmu agama dan pengetahuan umum. Nilai-nilai keimanan dan ketakwaan seolah-olah hanya merupakan bagian dari mata pelajaran pendidikan agama, sementara mata pelajaran yang lain mengajarkan ilmunya seolah-olah tidak ada hubungannya dengan masalah nilai keiman-an dan ketakwaan. ${ }^{27}$

Dampak berupa gejala kegersangan batin dan kejiwaan modern adalah konsekuensi dari hal itu. Bahkan pendi-dikan di dunia muslim pun berurat berakar mengadopsi konsep sekuler yang dikotomis dan tidak utuh. ${ }^{28}$

Model tersebut tampak dikembangkan pada sekolah yang di dalamnya diberikan seperangkat mata pelajaran atau ilmu pengeta-huan, yang salah satunya adalah mata pelajaran pendidikan agama yang hanya diberikan 2 atau 3 jam pelajaran per minggu, dan di-dudukkan sebagai mata pelajaran, yakni sebagai upaya pembentu-kan kepribadian yang religius. Kebijakan ini sangat prospektif da-lam membangun watak, moral dan peradaban bangsa yang ber-martabat. Namun demikian, dalam realitasnya pendidikan agama Islam sering termarginalkan, bahkan guru PAI di sekolah pun ka-dang-kadang terhambat karirnya untuk menggapai jabatan fungsi-onal tertinggi, karena tidak tersedia program studi sebagai induknya. $^{29}$

Kebijakan tentang pembinaan pendidikan agama Islam secara terpadu di sekolah

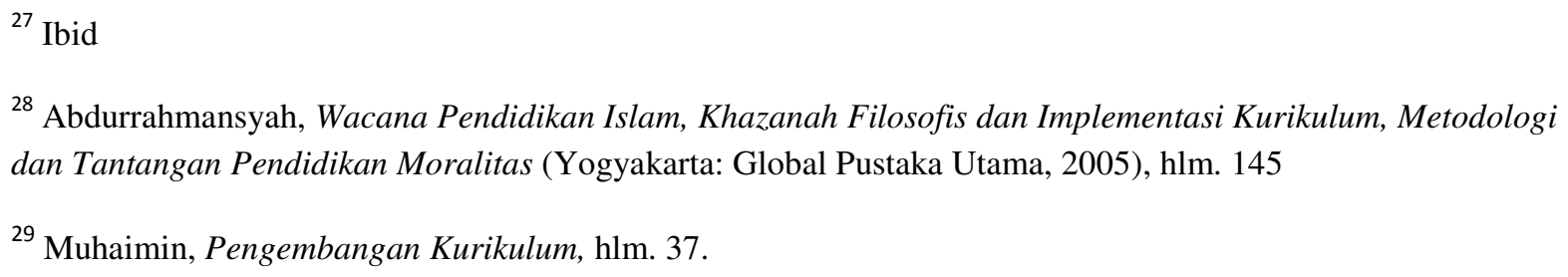


umum misalnya, antara lain menghendaki agar pendidikan agama dan sekaligus para guru agamanya mampu me-madukan antara mata pelajaran agama dengan pelajaran umum. Kebijakan ini akan sulit diimplementasikan pada sekolah yang cu-kup puas hanya mengembanhkan pola relasi horizontal-lateral

(independent). Barangkali kebijakan tersebut relatif mudah diimple-mentasikan pada lembaga pendidikan yang mengembangkan pola lateral-sekuensial. Hanya saja implikasi dari kebijakan tersebut ada-lah para guru agama harus menguasai ilmu agama dan memahami substansi ilmu-ilmu umum, sebaliknya guru umum dituntut untuk menguasai ilmu umum (bidang keahliannya) dan memahami ajar-an dan nilai-nilai agama. Bahkan guru agama dituntut untuk mam-pu menyusun buku-buku teks keagamaan yang dapat menjelaskan hubungan antara keduanya. ${ }^{30}$

c. Model Organism/Sistemik

Meminjam istilah biologi, organism dapat berarti susunan yang bersistem dari berbagai bagian jasad hidup untuk suatu tujuan. Dalam konteks pendidikan Islam, model organism bertolak dari pandangan bahwa aktivitas kependidikan merupakan suatu sistem yang terdiri atas komponen-komponen yang hidup bersama dan bekerja sama secara terpadu menuju tujuan tertentu, yaitu terwu-judnya hidup yang religius atau dijiwai oleh ajaran dan nilai-nilai agama. ${ }^{31}$

Pandangan tersebut menggarisbawahi pentingnya kerangka pe-mikiran yang dibangun dari fundamental doctrines dan fundamental values yang tertuang dan terkandung dalam alQur'an dan al-Sunnah al-Shahîhah sebagai sumber pokok. Ajaran dan nilai-nilai ilahi ${ }^{32}$ didudukkan sebagai sumber konsultasi yang bijak, sementa-ra aspek kehidupan lainnya didudukkan sebagai nilai-nilai insani ${ }^{33}$

\footnotetext{
${ }^{30}$ Ibid, hlm. 37-38

${ }^{31}$ Muhaimin, Rekonstruksi Pendidikan Islam, hlm. 67

${ }^{32}$ Nilai ilahi merupakan nilai yang dititahkan Tuhan melalui para rasul-Nya, yang berbentuk takwa, iman dan adil yang diabdikan dalam wahyu ilahi. Nilai-nilai ilahi selamanya tidak mengalami perubahan. Nilai-nilai yang fundamental mengandung kemutlakan bagi kehidupan manusia selaku pribadi dan selaku anggota masyarakat serta tidak berkecenderungan untuk merubah mengikuti selera hawa nafsu manusia dan berubah sesuai dengan tuntutan perubahan sosial dan tuntutan individual. Konfigurasi dari nilai-nilai ilahi mungkin berubah, namun secara instrinsiknya tetap tidak berubah. Hal ini karena bila instrinsik nilai tersebut berubah, maka kewahyuan (revillatif) dari sumber nilai yang berupa kitab suci al-Qur'an akan mengalami kerusakan. Lihat Arifin, Filsafat Pendidikan Islam, hlm. 121

${ }^{33}$ Muhaimin, Rekonstruksi Pendidikan Islam, hlm. 67.
} 
yang mempunyai hubungan vertikal-linier dengan nilai ilahi/aga-ma. ${ }^{34}$

Nilai ilahi dalam aspek teologi tak pernah mengalami peru-bahan, ${ }^{35}$ sedangkan aspek amaliahnya mungkin mengalami peru-bahan sesuai dengan tututan zaman dan lingkungan. Sebaliknya nilai insani selamanya mengalami perkembangan dan perubahan menuju ke arah yang lebih maju dan lebih tinggi. Tugas pendidikan adalah memadukan nilai- nilai baru dengan nilai-nilai lama secara selektif, inovatif, dan akomodatif guna mendinamisasikan perkem-bangan pendidikan yang sesuai dengan tuntutan zaman dan keada-an, tanpa meninggalkan nilai fundamental yang menjadi tolok ukur bagi nilai-nilai baru.

Melalui upaya semacam itu, maka sistem pendidikan Islam diharapkan dapat mengintegrasikan nilai-nilai ilmu pengetahuan, nilai-nilai agama dan etik, serta mampu melahirkan manusia-ma-nusia yang menguasai dan menerapkan ilmu pengetahuan, teknologi dan seni, memiliki kematangan profesional, dan sekaligus hidup di dalam nilai-nilai agama.

Paradigma tersebut tampaknya mulai dirintis dan dikembang-kan dalam sistem pendidikan di madrasah, yang dideklarasikan sebagai sekolah umum yang berciri khas agama Islam, atau seko-lah-sekolah (swasta) Islam unggulan. Kebijakan pengembangan madrasah berusaha mengakomodasikan tiga kepentingan utama, yaitu: pertama, sebagai wahana untuk membina roh atau praktik hi-dup keislaman; kedua, memperjelas dan memperkokoh keberadaan madrasah sederajat dengan sistem sekolah, sebagai pembinaan warga negara yang cerdas berpengetahuan, berkepribadian, serta produktif; dan ketiga, mampu merespon tuntutan-tuntutan masa depan dalam arti sanggup melahirkan manusia yang memiliki ke siapan memasuki era globalisasi, industrialisasi maupun era infor-masi. ${ }^{36}$

Maka dari itu, model organisme/sistemik dapat diimplementasi-kan dalam pengembangan pendidikan agama Islam di sekolah, meng-ingat kegiatan pendidikan agama yang berlangsung selama ini lebih banyak bersikap menyendiri, kurang berinteraksi dengan kegiatan-kegiatan pendidikan lainnya. Cara kerja semacam ini kurang efektif untuk keperluan penanaman suatu perangkat nilai yang kompleks. Selain itu, metodologi pendidikan agama kurang mendorong penjiwa-an terhadap nilai-nilai kegamaan serta terbatasnya bahan-bahan baca-an keagamaan. Buku-buku paket pendidikan agama saat ini belum memadai untuk

\footnotetext{
${ }^{34}$ Ibid

${ }^{35}$ Zuhairini, et.al. Filsafat Pendidikan Islam (Jakarta: Bumi Aksara, 1992), hlm.56

${ }^{36}$ Muhaimin, Rekonstruksi Pendidikan Islam, hlm. 68
} 
membangun kesadaran beragama, memberikan kete-rampilan fungsional keagamaan dan mendorong perilaku bermoral dan berakhlak mulia pada peserta didik.

\section{Penutup}

Kegiatan pendidikan agama yang berlangsung selama ini lebih banyak bersikap menyendiri, kurang berinteraksi dengan kegiatan-kegiatan pendidikan lainnya. Cara kerja semacam ini kurang efektif untuk keperluan penanaman suatu perangkat nilai yang efektif untuk keperluan penanaman suatu perangkat nilai yang kompleks. Selain itu, metodologi pendidikan agama kurang mendorong penjiwaan terhadap nilai-nilai kegamaan serta terbatasnya bahan-bahan bacaan keagamaan. Buku-buku paket pendidikan agama saat ini belum me-madai untuk membangun kesadaran beragama, memberikan keteram-pilan fungsional keagamaan dan mendorong perilaku bermoral dan berakhlak mulia pada peserta didik.

Untuk itu, diperlukan pengembangan pendidikan agama yang le-bih kondusif dan prospektif terutama di sekolah. Model pengem-bangannya perlu direkonstruksi, dari model yang bersifat dikotomis dan mekanisme ke arah model organisme atau sistemik. Hanya saja untuk merombak model tersebut diperlukan kemampuan guru PAI dan political will dari para pengambil kebijakan, termasuk di dalamnya para pimpinan lembaga pendidikan itu sendiri. Wa Allâh a'lam bi al-shawâb.* 


\section{DAFTAR PUSTAKA}

Baharun, Hasan, and Akmal Mundiri, Metodologi Studi Islam: Percikan Pemikiran Tokoh Dalam Membumikan Agama, Ar-Ruzz. Media, 1st edn (Yogyakarta: Ar-Ruzz Media, 2011)

Mundiri, Akmal, 'KOMITMEN ORGANISASIONAL SUMBER DAYA MANUSIA DALAM MENINGKATKAN MUTU PENDIDIKAN PESANTREN', Pedagogik, 3 (2015), 88-105

Mundiri, Akmal, and Irma Zahra, 'IMPLEMENTASI METODE STIFIn DALAM MENINGKATKAN KEMAMPUAN MENGHAFAL AL-QUR'AN DI RUMAH QUR'AN STIFIn PAITON PROBOLINGGO', Journal of Islamic Education Studies), 5 (2017), 201-23 <https://doi.org/10.15642/jpai.2017.5.2.201-223> 